\title{
A great volcanic eruption around AD 1300 recorded in lacustrine sediment from Dongdao Island, South China Sea
}

\author{
Zhongkang Yang ${ }^{1}$, NAnye Long ${ }^{1}$, Yuhong WAng $^{1}$, Xin Zhou ${ }^{1}$, Yi Liu ${ }^{2}$ and Liguang Sun ${ }^{1, *}$ \\ ${ }^{1}$ Institute of Polar Environment, School of Earth and Space Sciences, University of Science and \\ Technology of China, Hefei, Anhui 230026, People's Republic of China. \\ ${ }^{2}$ National Synchrotron Radiation Laboratory, University of Science and Technology of China, Hefei, \\ Anhui 230026, People's Republic of China. \\ *Corresponding author. e-mail: slg@ustc.edu.cn
}

The contents of $\mathrm{Ti}, \mathrm{Al}$ and $\mathrm{Fe}_{2} \mathrm{O}_{3}$ in a lacustrine sediment core (DY6) collected from Dongdao Island, South China Sea (SCS), were determined to be much higher than those in the three major sediment endmembers (coral sand, guano and plants), and their likely sources include terrigenous dust and volcanic ash. At $61 \mathrm{~cm}(\sim \mathrm{AD} 1300)$, the contents of $\mathrm{Ti}, \mathrm{Al}$ and $\mathrm{Fe}_{2} \mathrm{O}_{3}$ have an abnormally high spike, which cannot be explained by terrigenous dust. The $\mathrm{Sr}$ and $\mathrm{Nd}$ isotope compositions at $61 \mathrm{~cm}$ are in excellent agreement with those in volcanic materials, but they are significantly different from those in terrigenous dust, implying a possible material input from historical volcanic eruptions in the lacustrine sediment DY6. The documented great Samalas volcanic eruption at AD 1257 in Indonesia is likely the candidate for this volcanic eruption.

\section{Introduction}

Volcanic activity is an important factor in global climate change. The large amount of magma, volcanic gases and volcanic ash injected from the inner crust into the atmosphere can change atmospheric composition, influence solar radiation and cause hydrological cycle changes and climate cooling (Kelly and Sear 1984; Briffa et al. 1998; Trenberth and Dai 2007). As a consequence, crops and vegetation can be detrimentally affected (McGlone et al. 1988), and severe flooding disasters may occur (Trenberth and Dai 2007). Progresses have been made in identifying volcanic substances and reconstructing volcanic eruption records (Zielinski et al. 1994; Mann et al. 2005; Plummer et al. 2012). Zielinski et al. (1994) reconstructed a record of volcanic eruptions since $7000 \mathrm{BC}$ in northern hemisphere through sulphate content in the Greenland ice core. Plummer et al. (2012) reconstructed a 2000-yr volcanic record from Law Dome, East Antarctica. Similar works also used deep sea sediment (Ninkovich 1968; Watkins et al. 1978) and obvious tephra layers in lake sediment (Kilian et al. 2003; Haberzettl et al. 2008).

However, to our knowledge, lacustrine sediment in the SCS, without obvious tephra layers, has rarely been used to reconstruct volcanic eruption records. In this study, we determined the content of $\mathrm{Ti}, \mathrm{Al}$ and $\mathrm{Fe}_{2} \mathrm{O}_{3}$ and isotope composition of $\mathrm{Sr}$ and $\mathrm{Nd}$ in the sediment core from Dongdao Island of the South China Sea in order to identify volcanic materials and eruptions.

\section{Materials and methods}

\subsection{Study area}

Dongdao Island $\left(16^{\circ} 39^{\prime} \sim 16^{\circ} 41^{\prime} \mathrm{N}, 112^{\circ} 43^{\prime} \sim 112^{\circ}\right.$ $45^{\prime} \mathrm{E}$ ) is located to the east of Xisha Islands; it is

Keywords. South China Sea; element analysis; Sr and Nd isotope compositions; volcanic ash; AD 1257 Samalas. 
18 miles away from the biggest island, Yongxing Island, in Xisha. Dongdao Island is a typical, elliptical coral island with a northwest to southeast orientation (figure 1), it has a total area of about $1.55 \mathrm{~km}^{2}$, and it is about $3-6 \mathrm{~m}$ above sea level. The island is derived from an individual coral flat and formed since mid-late Holocene. The southern, western and eastern shores of the island are surrounded by 5-6 $\mathrm{m}$ high sand barriers, deposited by coral fragments, and covered by thriving vegetation, including mainly, Scaevalo sericca and Messerschmidia argentia. There is a flat island basin inside the sand barriers with large tracts of Pisonia grandis. The island has an annual temperature of $26 \sim 27^{\circ} \mathrm{C}$ and an annual rainfall of $1500 \mathrm{~mm}$. Dry and wet seasons are distinct, with the wet season spanning from June to November and the dry season from December to May of the next year (Lin et al. 1999).

Cattle Pond, a crescent-like brackish water lake, is located near the south-western sand barriers of
Dongdao Island (figure 1c). It is about $150 \mathrm{~m}$ long with a maximum width of $15 \mathrm{~m}$. The water level is usually below $0.5 \mathrm{~m}$ and varies with alternation between dry and wet seasons (Liu et al. 2006, 2008).

\subsection{Sample collection and analytical methods}

Sediment core DY6 (158 cm long) was collected from Cattle Pond using clean PVC plastic pipes of a diameter of $12 \mathrm{~cm}$. The sediment cores were stored in a lab freezer until analysis. In the lab, DY6 was sectioned at $0.5 \mathrm{~cm}$ intervals. Samples were air-dried in a clean lab environment and homogenized.

The air-dried samples were ground to powder after removal of large plant and animal remains. About $0.25 \mathrm{~g}$ of each powder sample was taken and then digested by multi-acids in a PTFE crucible, until the acid liquid was pellucid. Following
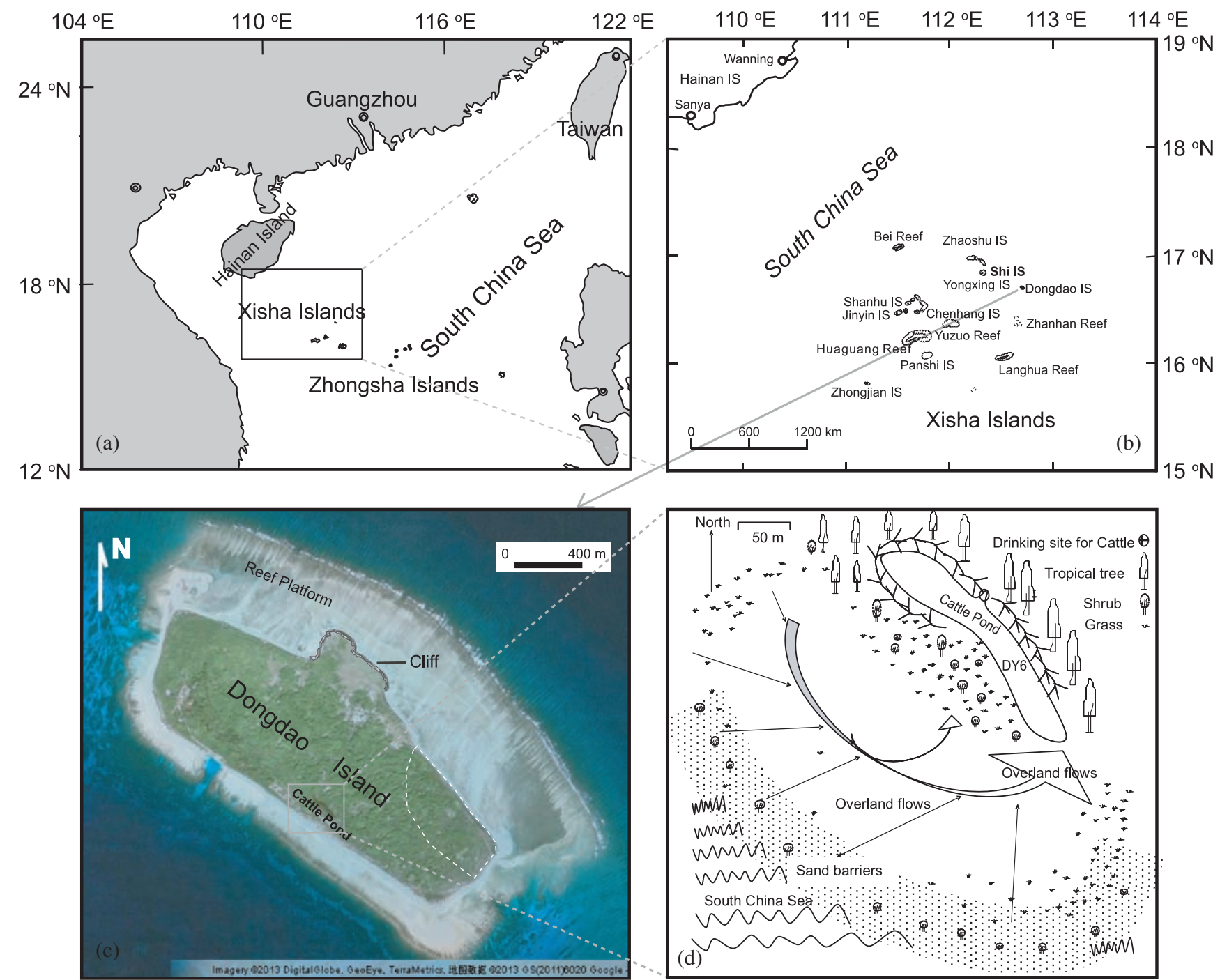

Figure 1. Maps of study locations. (a and b) Geographical location of Xisha Islands; (c) terrain characteristics of Dongdao Island; and (d) sampling sites of sediment cores DY6 in Cattle Pond. 
this, the remains were dissolved and analysed for $\mathrm{Ti}, \mathrm{Al}, \mathrm{Fe}$ as well as other inorganic elements by Inductive Coupled Plasma-Atomic Emission Spectrometry (P.E Ltd, Optima 2100 DV). The analytical errors for major and trace elements were within $\pm 0.5 \%$ and $\pm 5 \%$, respectively. The ${ }^{87} \mathrm{Sr} /{ }^{86} \mathrm{Sr}$ and ${ }^{143} \mathrm{Nd} /{ }^{144} \mathrm{Nd}$ ratios were performed on the acid-insoluble remains at $61 \mathrm{~cm}$ of the sediment core. $\mathrm{Nd}$ isotopic ratios are expressed as $\varepsilon_{\mathrm{Nd}}(0)=\left[\left(\left({ }^{143} \mathrm{Nd} /{ }^{144} \mathrm{Nd}_{\text {means }}\right) / 0.512638\right)-1\right] \times 1000$. A more detailed description of analytical method is given by Liu et al. (2014).

\section{Results and discussion}

\subsection{Chronology of DY6}

Reliable chronology of DY6 was established based on AMS ${ }^{14} \mathrm{C}$ dating of some caryopses and ${ }^{210} \mathrm{~Pb}$ dating of the upper part of the sediment core. Considering that both DY4 (Liu et al. 2006) and DY6 were sampled from the same lake, it is reasonable to assume that they have the same lithological and physicochemical characteristics. Consequently, the dating results of DY4 were used to modify the chronology of DY6 according to their lithological characteristics and detailed results were reported previously by Liu et al. (2014).

\subsection{Identification of foreign material input}

Our earlier analysis of sedimentary facies of three parallel sediment cores DY2, DY4 and DY6 has indicated that the three major sediment endmembers in Cattle Pond are coral sand, guano and plants (Zhao et al. 2007; Liu et al. 2013). Considering the ambient environment of Cattle Pond, it is difficult to find other obvious indigenous material input into Cattle Pond, according to our field observations. The average $\mathrm{Ti}$ and $\mathrm{Al}$ contents in sediment core DY6 are 4.25 and $110.6 \mathrm{mg} / \mathrm{kg}$, respectively, the maximum content of $\mathrm{Fe}_{2} \mathrm{O}_{3}$ is
$382 \mathrm{mg} / \mathrm{kg}$, and contents of the three elements in DY6 are obviously much higher than those in the three major sediment end-members (table 1).

The sediments mainly produced by coral sand in Dongdao Island contain little diagenetic elements like $\mathrm{Ti}$ and $\mathrm{Al}$ (Liu et al. 2013). Input of plants also cannot change the contents of $\mathrm{Ti}, \mathrm{Al}$ and $\mathrm{Fe}_{2} \mathrm{O}_{3}$ dramatically in sediments. Although, guano may influence element contents to some extent, input of seabird guano cannot explain the extremely high concentration of $\mathrm{Ti}, \mathrm{Al}$ and $\mathrm{Fe}_{2} \mathrm{O}_{3}$ because proportion of seabird guano in DY6 is very low. Thus, the extremely high contents of $\mathrm{Ti}, \mathrm{Al}$ and $\mathrm{Fe}_{2} \mathrm{O}_{3}$ are likely derived from alien materials.

Through geochemical and morphological analyses of acid-insoluble particles in the sediment core DY6, Liu et al. (2013) reported alien material input from terrigenous dust. In addition, we also found basalt on the island in our fieldwork. The basalt is black with vesicular structure (figure 2). Basalt is unlikely indigenous to Dongdao Island because of its sediment provenance and ambient environment characteristics. Furthermore, $\mathrm{Ti}, \mathrm{Al}$ and $\mathrm{Fe}_{2} \mathrm{O}_{3}$ contents of basalt are much higher than those in the three major sediment end-members and sediment core DY6. Therefore, input of volcanic materials in DY6 is likely.

\subsection{Volcanic ash as the alien source in the sediment core DY6}

Liu et al. (2014) reported that the studied area has been influenced by terrigenous dust using $\mathrm{Sr}$ and $\mathrm{Nd}$ isotope compositions (acid-insoluble remains at 100-102 $\mathrm{cm}(\sim \mathrm{AD} 1070)$ and $140-154 \mathrm{~cm}$ (AD 700 800)) (figure 3) and established a 1400 year record of dust flux in the SCS through Ti flux. Compared with down-core variations of $\mathrm{Ti}, \mathrm{Al}$ and $\mathrm{Fe}_{2} \mathrm{O}_{3}$ from DY6, we found a distinct peak at $\sim \mathrm{AD}$ 1300 (figure 4). Interestingly, the peak of each content at $\sim \mathrm{AD} 1300$ has a totally different shape when compared to peaks at $\mathrm{AD} 700 \sim 800$ and $\mathrm{AD}$

Table 1. Al, Ti, $\mathrm{Fe}_{2} \mathrm{O}_{3}$ contents and variation range in sediment core DY6, basalt and three major sediment end-members.

\begin{tabular}{|c|c|c|c|c|}
\hline \multicolumn{2}{|c|}{ Element } & $\mathrm{Al}(\mathrm{mg} / \mathrm{kg})$ & $\mathrm{Ti}(\mathrm{mg} / \mathrm{kg})$ & $\mathrm{Fe}_{2} \mathrm{O}_{3}(\mathrm{mg} / \mathrm{kg})$ \\
\hline \multirow{2}{*}{ Coral sand $(n=3)$} & Average & 6.2 & ND & $\mathrm{ND}$ \\
\hline & Variation & $5.5 \sim 6.9$ & ND & $\mathrm{ND}$ \\
\hline \multirow{2}{*}{ Plants $(\mathrm{n}=6)$} & Average & 10.4 & 0.35 & 34.0 \\
\hline & Variation & $3.9 \sim 19.5$ & $0 \sim 0.95$ & $20.9 \sim 62.1$ \\
\hline \multirow{2}{*}{ Guano $(n=3)$} & Average & 3.45 & ND & 256.6 \\
\hline & Variation & $1.8 \sim 5.1$ & ND & $252 \sim 262$ \\
\hline \multirow{2}{*}{ Basalt $(\mathrm{n}=3)$} & Average & 95651.3 & 5498.7 & 65310.1 \\
\hline & Variation & $94924.8 \sim 96745.8$ & $5356.2 \sim 5685.6$ & $62519.1 \sim 67918.0$ \\
\hline \multirow{2}{*}{ Sediment $(n=314)$} & Average & 110.6 & 4.25 & 120.4 \\
\hline & Variation & $15 \sim 1002$ & $0 \sim 106.7$ & $18 \sim 382$ \\
\hline
\end{tabular}

Note: ND means below the limit of detection. 


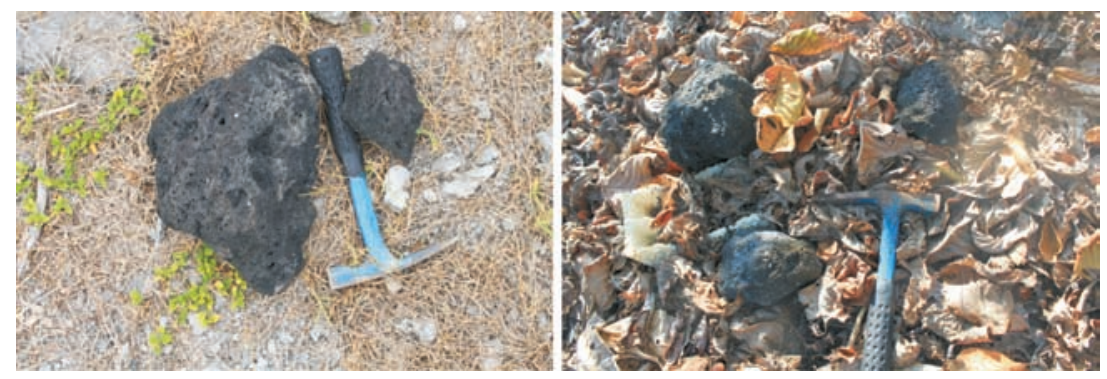

Figure 2. Basalt, discovered during field investigation, is not indigenous to Dongdao Island according to the analysis of source origin.

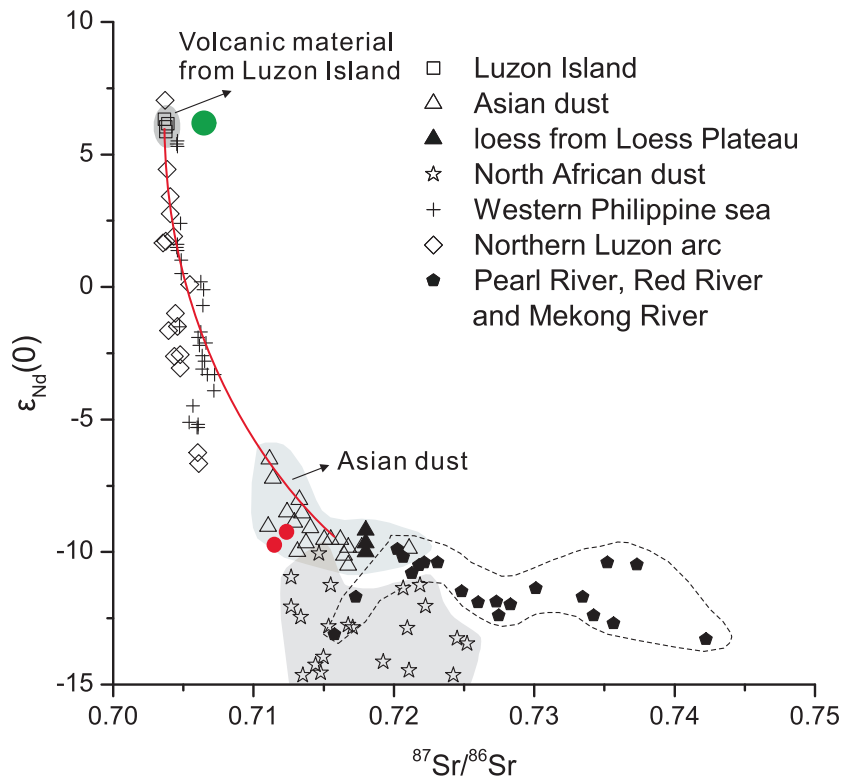

Figure 3. $\varepsilon_{\mathrm{Nd}}(0)$ values plotted against ${ }^{87} \mathrm{Sr} /{ }^{86} \mathrm{Sr}$ ratios of samples from different locations, including Asian dust, North African dust, volcanic materials from Luzon Island, loess from Loess Plateau and sediments from Western Philippine sea, Northern Luzon arc and Pearl River, Red River and Mekong River. The green point is the ${ }^{87} \mathrm{Sr} /{ }^{86} \mathrm{Sr}-\varepsilon_{\mathrm{Nd}}(0)$ isotope compositions of acid-insoluble particles in DY 6 at 61 $\mathrm{cm}$ (AD 1300), while the red points represent the ${ }^{87} \mathrm{Sr} /{ }^{86} \mathrm{Sr}$ $-\varepsilon_{\mathrm{Nd}}(0)$ isotope compositions of acid-insoluble particles in DY6 at $100-102 \mathrm{~cm}(\sim \mathrm{AD} 1070)$ and $140-154 \mathrm{~cm}$ (AD $700 \sim 800)$, respectively. The red line is the mixing curve of volcanic materials and eolian dust (figure modified based on Jiang et al. 2013 and Liu et al. 2014).

1000 1100. The peak at $\sim$ AD 1300 appears abrupt and is very sharp, suggesting a sudden event at $\sim \mathrm{AD} 1300$, while the peaks at $\mathrm{AD} 700 \sim 800$ and AD 1000 1100 are flat and these three elements stay at a relatively high level for more than 100 years. The variations of $\mathrm{Fe}_{2} \mathrm{O}_{3}$ content are very similar to Ti flux changes during the past 1400 years, except at $\sim \mathrm{AD} 1300$; at this point, the content of $\mathrm{Fe}_{2} \mathrm{O}_{3}$ is very high, but the dust flux is not. The spikes of $\mathrm{Al}$ and Ti only emerged at $\sim \mathrm{AD} 1300$ and their contents are far higher than those in other periods. Thus, the extremely high content of $\mathrm{Ti}$,

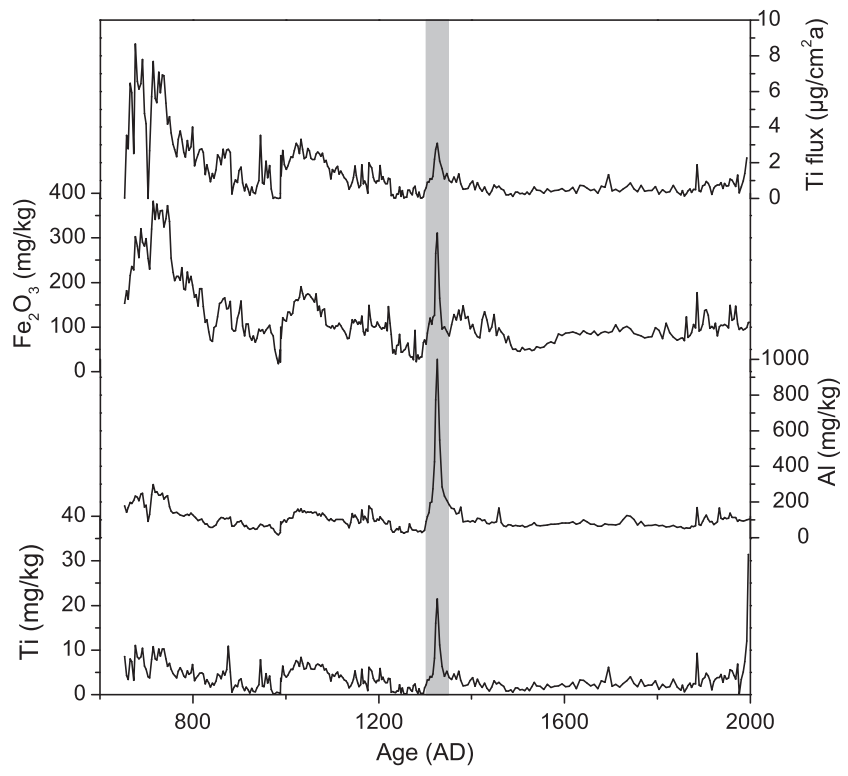

Figure 4. Comparisons between Ti flux (Liu et al. 2014) and contents of $\mathrm{Al}, \mathrm{Ti}$ and $\mathrm{Fe}_{2} \mathrm{O}_{3}$ in sediment core DY6. The shaded area marks spike of $\mathrm{Ti}$ flux and contents of $\mathrm{Al}, \mathrm{Ti}$ and $\mathrm{Fe}_{2} \mathrm{O}_{3}$, all of which emerged at about the same time, around AD 1300.

$\mathrm{Al}$ and $\mathrm{Fe}_{2} \mathrm{O}_{3}$ at $\sim \mathrm{AD} 1300$ are most likely due to input of alien materials other than terrigenous dust.

Because $\mathrm{Ti}, \mathrm{Al}$ and $\mathrm{Fe}_{2} \mathrm{O}_{3}$ content is known to be high in volcanic materials (Genshaft et al. 1984; Muhs and Budahn 2009) and the spike of $\mathrm{Ti}, \mathrm{Al}$ and $\mathrm{Fe}_{2} \mathrm{O}_{3}$ occurs so abruptly, we propose here that the abnormally high contents of $\mathrm{Ti}, \mathrm{Al}$ and $\mathrm{Fe}_{2} \mathrm{O}_{3}$ at $\sim \mathrm{AD} 1300$ come from a possible volcanic eruption. To confirm this, we performed a subsequent $\mathrm{Sr}-\mathrm{Nd}$ isotope analysis, and determined the $\mathrm{Sr}$ and $\mathrm{Nd}$ isotope compositions of acid-insoluble remains at $61 \mathrm{~cm}(\sim \mathrm{AD} 1300)$ in DY6. As seen from figure $3, \mathrm{Sr}$ and $\mathrm{Nd}$ isotope compositions of terrigenous dust and volcanic materials are significantly different from each other. The ${ }^{87} \mathrm{Sr} /{ }^{86} \mathrm{Sr}$ and $\varepsilon_{\mathrm{Nd}}(0)$ values at $61 \mathrm{~cm}$ are consistent with those in volcanic materials (figure 3 ), and the ${ }^{87} \mathrm{Sr} /{ }^{86} \mathrm{Sr}$ and $\varepsilon_{\mathrm{Nd}}(0)$ isotope compositions of acid-insoluble particles at $100-102 \mathrm{~cm}(\sim \mathrm{AD} 1070)$ and 140 $154 \mathrm{~cm}$ (AD 700 800) are consistent with those 
Table 2. Volcanic eruption list recorded from GISP2 (Zielinski et al. 1994) and Law Dome (Plummer et al. 2012).

\begin{tabular}{|c|c|c|c|c|}
\hline \multirow{3}{*}{$\begin{array}{l}\text { Year of } \\
\text { signal }\end{array}$} & \multicolumn{2}{|c|}{ Greenland ice core (GISP2) } & & \\
\hline & \multirow{2}{*}{$\begin{array}{c}\mathrm{SO}_{4}^{2-} \text { residual } \\
(\mathrm{ppb})\end{array}$} & \multirow[b]{2}{*}{ Volcanic eruption with year } & \multicolumn{2}{|c|}{ Law Dome } \\
\hline & & & Year of signal & Volcanic eruption \\
\hline 1205 & 32 & Oshima, Japan, $1200 \pm 50$ & 1229 & Unknown \\
\hline 1227 & 34 & Unknown & 1257 & Samalas, 1257 \\
\hline 1229 & 78 & Unknown & 1268 & Unknown \\
\hline 1259 & 349 & Samalas, Indonesia, 1257 & 1275 & Unknown \\
\hline 1285 & 44 & Unknown, Asama, Japan, 1281 & 1344 & Unknown \\
\hline 1328 & 33 & Cerro Bravo, Columbia, $1325 \pm 75$ & & \\
\hline 1344 & 54 & Hekla, Iceland, 1341 & & \\
\hline
\end{tabular}

Note: We referred to Lavigne et al. (2013) for the AD 1257 Samalas volcanic eruption.

in eolian dust (Liu et al. 2014). Thus, the $\mathrm{Sr}$ and $\mathrm{Nd}$ isotope values clearly show that volcanic ash is the primary contributor of the $\mathrm{Ti}, \mathrm{Al}$ and $\mathrm{Fe}_{2} \mathrm{O}_{3}$ content anomaly at $\sim \mathrm{AD} 1300$. Isotope composition analysis is, thus, an indispensable tool to distinguish between different material sources of sediments.

\subsection{Potential candidate for $\sim A D 1300$ volcanic eruption}

In order to find out the possible, recorded, volcanic eruption that is responsible for the sudden $\mathrm{Ti}, \mathrm{Al}$ and $\mathrm{Fe}_{2} \mathrm{O}_{3}$ contents anomaly at $\sim \mathrm{AD} 1300$ of DY6, we compiled a list of volcanic eruptions between AD 1200 and 1400, recorded in GISP2 Greenland ice core (Zielinski et al. 1994) and Law Dome (Plummer et al. 2012) (table 2). There are 4 known volcanic eruptions around AD 1300. However, three of them are from Iceland, Columbia and Japan, far from the SCS, and their magnitude is also relatively small; thus these three volcanic eruptions are unlikely the candidate for the $\sim \mathrm{AD} 1300$ volcanic eruption in SCS. One great volcanic eruption (Lavigne et al. 2013) took place in AD 1257 in Samalas, Indonesia, very close to the SCS, and it is the greatest volcanic eruption of the past 7000 years. This huge volcanic event was also suggested by the research findings from Plummer et al. (2012), Zielinski et al. (1994) and Mann et al. (2005). Thus, the volcanic ashes from the Samalas eruption in AD 1257 were most likely transferred and precipitated in Dongdao Island.

The difference between our inferred time of $\mathrm{AD}$ 1300 and the Samalas eruption time of AD 1257 can be attributed to some error induced by the ${ }^{14} \mathrm{C}$ dating method. In our study, the chronology of sediment core was established by linear interpolation and by assuming constant sedimentation rate along different layers, which may not always be true. Although, our identified time is not precisely AD 1257, it is nevertheless within the allowed error range. Further research and confirmation is apparently needed.

\section{Conclusions}

At $61 \mathrm{~cm}(\sim \mathrm{AD} 1300)$ in the sediment core DY6, the $\mathrm{Ti}, \mathrm{Al}$ and $\mathrm{Fe}_{2} \mathrm{O}_{3}$ contents are abnormally high, indicating alien sources such as eolian dust and volcanic ashes. Since the dust flux is relatively low and the peaks of $\mathrm{Al}$, Ti and $\mathrm{Fe}_{2} \mathrm{O}_{3}$ at around $\mathrm{AD}$ 1300 are much sharper than those at $\sim \mathrm{AD} 750$ and AD 1050, eolian dust is unlikely the primary source of $\mathrm{Al}$, Ti and $\mathrm{Fe}_{2} \mathrm{O}_{3}$ at $\sim \mathrm{AD}$ 1300. The $\mathrm{Sr}$ and $\mathrm{Nd}$ isotope compositions at $61 \mathrm{~cm}$ are in excellent agreement with those in volcanic materials, but they are significantly different from those in terrigenous dust. Thus, the $\mathrm{Ti}, \mathrm{Al}$ and $\mathrm{Fe}_{2} \mathrm{O}_{3}$ content anomaly is caused by volcanic material input, and the documented great Samalas volcanic eruption at AD 1257, in Indonesia, likely accounts for that eruption.

\section{Acknowledgements}

The research was supported by 'Strategic Priority Research Program' of the Chinese Academy of Sciences (XDA11030104) and Key Research Program of the Chinese Academy of Sciences (KZZDEW-TZ-15-2). We are grateful to the P R China troops in $\mathrm{Xi}-\mathrm{Sha}$ atoll for their assistance in sampling.

\section{References}

Briffa K R, Jones P D, Schweingruber F H and Osborn T J 1998 Influence of volcanic eruptions on Northern Hemisphere summer temperature over the past 600 years; Nature 393 450-455.

Genshaft Y S, Pecherskiy D M, Borsuk A M and Tsvetkov 1984 Titanomagnetite in magmatic rocks of the Komandorskiye Island as indicators of the geodynamic regime; Int. Geol. Rev 26 1071-1081.

Haberzettl T et al. 2008 Hydrological variability in southeastern Patagonia and explosive volcanic activity in the southern Andean Cordillera during Oxygen Isotope Stage 3 and the Holocene inferred from lake sediments of Laguna Potrok Aike, Argentina; Palaeogeogr. Palaeoclimatol. Palaeoecol. 259 213-229. 
Jiang F, Frank M, Li T, Chen T, Xu Z and Li A 2013 Asian dust input in the western Philippine Sea: Evidence from radiogenic $\mathrm{Sr}$ and $\mathrm{Nd}$ isotopes; Geochem. Geophys. Geosys. 14 1538-1551.

Kelly P M and Sear C B 1984 Climatic impact of explosive volcanic eruptions; Nature 311 740-743.

Kilian R, Hohner M, Biester H, Wallrabe-Adams H J and Stern C R 2003 Holocene peat and lake sediment tephra record from the southernmost Chilean Andes (53-55 S); Revista Geológica de Chile 30 23-37.

Lavigne F et al. 2013 Source of the great AD 1257 mystery eruption unveiled, Samalas volcano, Rinjani Volcanic Complex, Indonesia; Proc. Nat. Acad. Sci. USA 110 $16,742-16,747$.

Lin X, Chen X, Wang F, Xiong S and Liu S 1999 The research report of climate investigation on sea islands of Hainan province; In: The professional proceedings of the integrated investigation research on sea islands resource of Hainan province; Beijing, China Ocean Press, pp. 24-35 (in Chinese).

Liu X et al. 2006 Geochemical evidence for the variation of historical seabird population on Dongdao Island of the South China Sea; J. Paleolimnol. 36 259-279.

Liu X, Sun L, Wei G, Wang Y, Yan H, Liu K and Wu X 2008 A 1100-year palaeoenvironmental record inferred from stable isotope and trace element compositions of ostracode and plant caryopses in sediments of Cattle Pond, Dongdao Island, South China Sea; J. Paleolimnol. 40 987-1002.

Liu Y, Sun L, Luo Y, Sun S and Wang Y 2013 Records of terrigenous dust in lacustrine sediments from Dongdao island, South China Sea; Mar. Geol. Quat. Geol. 33 (in Chinese with English abstract).

Liu Y, Sun L, Zhou X, Luo Y, Huang W, Yang C, Wang Y and Huang T 2014 A 1400-year terrigenous dust record on a coral island in South China Sea; Sci. Rep. UK 4.
Mann M E, Cane M A, Zebiak S E and Clement A 2005 Volcanic and solar forcing of the tropical Pacific over the past 1000 years; J. Climate 18 447-456.

McGlone M, Neall V and Clarkson B 1988 The effect of recent volcanic events and climatic changes on the vegetation of Mt Egmont (Mt Taranaki), New Zealand; New Zeal. J. Bot. 26 123-144.

Muhs D R and Budahn J R 2009 Geochemical evidence for African dust and volcanic ash inputs to terra rossa soils on carbonate reef terraces, northern Jamaica, West Indies; Quat. Int. 196 13-35.

Ninkovich D 1968 Pleistocene volcanic eruptions in New Zealand recorded in deep-sea sediments; Earth Planet. Sci. Lett. 4 89-102.

Plummer C, Curran M, Ommen T D, Rasmussen S, Moy A, Vance T, Clausen H, Vinther B and Mayewski P 2012 An independently dated 2000-yr volcanic record from Law Dome, East Antarctica, including a new perspective on the dating of the 1450s CE eruption of Kuwae, Vanuatu; Clim. Past. 8 1929-1940.

Trenberth K E and Dai A 2007 Effects of Mount Pinatubo volcanic eruption on the hydrological cycle as an analog of geoengineering; Geophys. Res. Lett. 34.

Watkins N, Sparks R, Sigurdsson H, Huang T, Federman A, Carey S and Ninkovich D 1978 Volume and extent of the Minoan tephra from Santorini Volcano: New evidence from deep-sea sediment cores; Nature 122-126.

Zhao S, Sun L, Liu X, Xie Z, Luo H, Liu K, Wu X, Ding X and $\mathrm{Fu} \mathrm{D} 2007$ Using $\mathrm{Sr} / \mathrm{Ca}$ and $\mathrm{Mg} / \mathrm{Ca}$ ratios as source indicators of ornithogenic lacustrine sediments on coral island; Quat. Sci. 27 149-156 (in Chinese with English abstract).

Zielinski G A, Mayewski P A, Meeker L D and Whitlow S 1994 Record of volcanism since 7000 BC from the GISP2 Greenland ice core and implications for the volcanoclimate system; Science 264 948-952. 